\title{
Restriction Fragment Length Polymorphisms in Rose and Their Use for Cultivar Identification
}

\author{
M. Hubbard, J. Kelly, S. Rajapakse, A. Abbott', and R. Ballard \\ Department of Horticulture, Clemson University, Clemson, SC 29634
}

Additional index words. Rosa hybrids, RFLP, DNA fingerprint, patent protection

Abstract; We have identified cloned rose DNA fragments that detect restriction fragment length polymorphisms (RFLP) in rose (Rosa $\times$ hybrida) cultivars. RFLP can be used as genetic markers for identification, certification, and patent protection. By comparing RFLP patterns for each of six probes, we have been able to characterize eight cultivars. These results confirm that RFLP analyses are useful for rose cultivar identification and may provide a means for protecting patent rights to new cultivars.

Patent infringement is a serious problem for rose breeders and companies that offer improved, patented cultivars, especially when the protected aspects of the plant are physically unidentifiable characteristics such as fragrance, disease resistance, and postharvest longevity. In the past, infringement has been difficult to prove, since no reliable technique has existed for accurately determining whether phenotypically similar roses are genetically different. Previous attempts to identify rose cultivars using isozyme patterns have been unsatisfactory, since tissue of a similar physiological age must be used to get reproducible banding patterns (Kuhns and Fretz, 1978). In addition, when compared with the size of the rose genome, the total number of loci that can be visualized with isozymes is small $(\approx 100)$ (Murphy et al., 1990); consequently, cultivars may be truly different without exhibiting any discernible differences in isozyme pattern. Recombinant DNA techniques, however, have now provided a method for using polymorphisms that can accurately demonstrate genetic differences among patented plants. These methods use restriction endonuclease-digested genomic DNA and cloned DNA probes for comparing the sequence of the DNA at a particular locus. Differences in the fragment lengths of restriction endonuclease-digested DNA (restriction fragment length polymorphisms, RFLP) are the consequence of heritable changes in the DNA, point mutations create or abolish restriction endonuclease sites, whereas DNA rearrangements,

Received for publication 26 Apr. 1991. This research was supported in part by funds from the South Carolina Agricultural Experiment Station Grant for the Enhancement of Research in Ornamental Horticulture-66-1303 and the National Science Foundation-R11-8922165. We appreciate the technical assistance and suggestions provided by Linda Eldredge. Part of a thesis to be submitted by M.H. in fulfillment of the requirements for a MS in horticulture. The cost of publishing this paper was defrayed in part by the payment of page charges. Under postal regulations, this paper therefore must be hereby marked advertisement solely to indicate this fact.

'Dept. of Biological Sciences. insertions, or deletions alter relative site positions.

Identification by RFLP has several advantages. Expression of RFLP is identical in all tissues, is detectable at any age of the plant, and is not affected by environmental conditions. Additionally, an unlimited number of loci can be examined and many alleles are likely to be found for each locus. Linkage mapping and cultivar identification are among the most valuable applications of RPLP. Linkage maps have been constructed with RFLP in diverse crop species, such as tomato (Lycopersicon esculentum Mill.) (Tanksley et al., 1988), and maize (Zea mays L.) (Helentjaris et al., 1986). RFLP use in cultivar identification has been demonstrated in soybean [Glycine $\max$ (L.) Merrill] (Apuya et al., 1988), barley (Hordeum vulgare L.) (Bunce et al., 1986), and potato (Solanum tuberosum L.) (Gebhardt et al., 1989). The use of RFLP in cultivar identification is very effective in differentiating those that do not breed true and are propagated asexually. These also are the plants most frequently covered by patents and for which breeders want to ensure that there has not been infringement of plant cultivar protection laws. Roses represent a major group of such patented plants. The objective of this research was to obtain RFLP probes that can be used as genetic markers in identification and patent protection of rose cultivars.

DNA isolation and library construction. Cultivars surveyed included 'Confection', 'Evening Star', 'Las Vegas', 'Love', 'Peace', 'Olympiad', 'Meijikatar', and 'Touch of Class'. DNA from each cultivar was extracted from $25 \mathrm{~g}$ of leaf tissue using hexadecyltrimethylammonium bromide (CTAB) (Bernatzky and Tanksley, 1986). Preference was given to the young, fully expanded leaves because they produced the greatest yield of DNA, although some mature leaves were collected and used. Leaves were stored at $-80 \mathrm{C}$ if not used immediately. DNA clones were generated from the rose 'Confection' by digesting 'Confection' DNA for $12 \mathrm{~h}$ at $37 \mathrm{C}$ with the restriction enzyme Hind III. The resulting fragments were ligated into the plasmid pUC8 (Messing, 1983), and the re- combinant plasmids were then transformed into the Escherichia coli bacterial strain JM83 (Maniatis et al., 1982).

Library screening. Clones containing nucleotide sequences that have few copies in the genome are the most useful for cultivar identification. Inserts containing highly repeated sequences will hybridize with so many fragments that individual DNA fragments are impossible to distinguish and, consequently, are not useful for cultivar identification. Clones were prescreened by hybridizing Southern blots (Southern, 1975) of restriction enzyme-digested DNA of individual plasmid clones with ${ }^{32} \mathrm{P}$-labelled rose genomic DNA to select low-copy clones. For this assay, recombinant plasmids were purified (Maniatis et al., 1982) and digested with Hin dIII. Fe inserts were then separated from

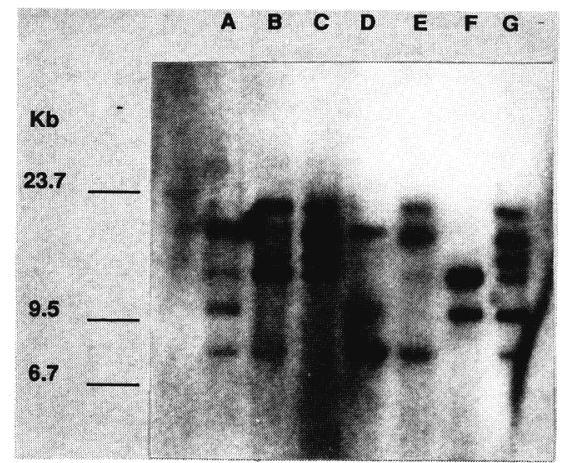

Fig. 1. Southern blot analysis of Eco RI-digested genomic DNA from Rosa cultivars with probe pH0.7C. (A) 'Las Vegas', (B) 'Evening Star', (C) 'Touch of Class', (D) 'Love', (E) 'Olympiad', (F) 'Meijikatar', and (G) 'Confection'. Size markers were derived from $\lambda$ DNA digested with Hin dIII plus pBR322 digested with Hin fI.

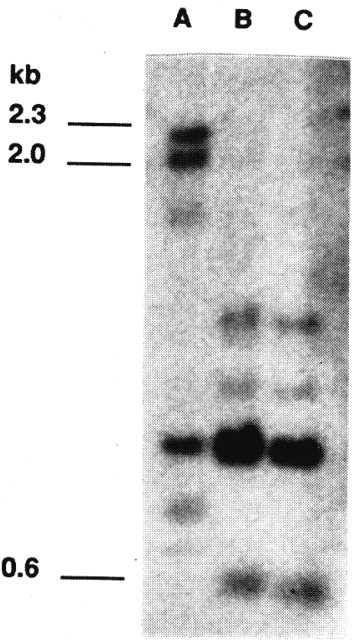

Fig. 2. Southern blot analysis of EcoRI-digested genomic DNA from three 'Peace' plants obtained from different sources with probe $\mathrm{pH} 1.3 \mathrm{C}$. (A) 'Peace' A, (B) 'Peace' B, (C) 'Peace' C. Size markers were derived from $\lambda$ DNA digested with Hin dIII 
the plasmids on $0.8 \%$ agarose gels. DNA clones previously determined to carry lowcopy and highly repeated sequences (as described below) were included on each gel for use in determining the copy count of each insert being screened. Phage $\lambda$ DNA digested with Hin dIII or $\lambda$ Hin dIII plus pBR322 digested with $\mathrm{Hin}$ fI were included for use as size markers.

Gels were treated and blotted onto Hybond-N membrane (Amersham, Arlington Heights, Ill.) following the manufacturer's instructions, after which the DNA was covalently bound to the membrane by UV radiation at $302 \mathrm{~nm}$ on a transilluminator (UVP, San Gabriel, Calif.); being kept there for 4 min. Hybridization was carried out at $65 \mathrm{C}$ in an incubator (Robbins Scientific, Sunnyvale, Calif.) with nick-translated $\left[\alpha{ }^{32} \mathrm{P}\right] \mathrm{dCTP}$ (DuPont, Wilmington, Del.) labelled genomic 'Confection' DNA (Maniatis et al., 1982). The membranes were autoradiographed at -80C from 2 to 10 days (depending on the strength of the hybridization signal), using Kodak X-OMAT XAR-5 film with one Cronex Lightning Plus intensifying screen (DuPont). Following autoradiography, the clones were scored for insert type using the following standard: clones with lowcopy sequences showed either a faint or no hybridization signal, and clones with highly repeated sequences produced a very intense signal. Only clones determined to carry lowcopy sequences were selected for these studies.

Cultivar comparison. DNA samples of individual rose cultivars were digested at $37 \mathrm{C}$ with the restriction enzyme Eco RI, electrophoresed on $0.8 \%$ agarose gels, and blotted onto Amersham Hybond-N membranes as previously described. Membranes were then hybridized with putative low-copy probes. To prepare the probes, recombinant plasmids were purified, digested, and separated as described. Inserts were isolated by electroelution from the agarose gel (Maniatis et al., 1982) and labelled with $\left[\alpha-{ }^{32} \mathrm{P}\right] \mathrm{dCTP}$ by random primer labelling (Feinberg and Vogelstein, 1983) to a specific activity of 1-5 $\times 10^{7} \mathrm{cpm} / \mathrm{pg}$ DNA. Following autoradiography, membranes were stripped of the ra- dioactive probe by washing the membrane gently in a $55 \%$ formamide, $2 \times$ SSPE $[0.15$ $\mathrm{M} \mathrm{NaCl}, 0.01 \mathrm{M}$ sodium phosphate, $0.001 \mathrm{M}$ EDTA, pH 7.41, $1 \%$ sodium dodecyl sulfate (SDS) solution at $65 \mathrm{C}$ for 45 to $90 \mathrm{~min}$ followed by a $1 \mathrm{~min}$ rinse in $0.1 \times \mathrm{SSC}[0.15$ $\mathrm{M} \mathrm{NaCl}, 0.015 \mathrm{M}$ trisodium citrate, $\mathrm{pH} 7.01$ and $0.1 \%$ SDS at room temperature.

Library screening. From the prescreening procedure, we determined that $80 \%$ of the 83 clones examined carried low-copy sequences. Twenty-three of these probes were effective in identifying RFLP, and six of those could be used to characterize several cultivars. Low-copy sequence probes yielding between three and 20 bands were the most effective for identifying cultivars.

Cultivar comparison. Six low-copy probes were used to distinguish rose cultivars. Some of these probes can differentiate among only two or three cultivars, whereas others can differentiate several cultivars. For example, probe $\mathrm{pH} 0.7 \mathrm{C}$ can identify all seven cultivars being compared on one gel (Fig. 1). By comparing RFLP patterns for each of our six probes, we have been able to characterize all eight cultivars that were examined.

This research also demonstrates the ability of RFLP to distinguish erroneously labelled cultivars. Three plants of 'Peace' obtained from different sources were compared. One of these plants, 'Peace' A, lacked the deep green, glossy foliage and cup-shaped flowers characteristic of 'Peace'. These morphological discrepancies were confirmed by a comparison of RFLP profiles for the three 'Peace' plants (Fig. 2). 'Peace' A is unquestionably different from 'Peace' B and 'Peace' C, whereas 'Peace' B and 'Peace' $\mathrm{C}$ are identical. These results were reproducible and verify that 'Peace' A was, in fact, not 'Peace'.

More extensive surveys (i.e., different restriction enzyme/probe combinations, comparisons of the same cultivar from different sources, comparison of a wider diversity of cultivars) will be needed to corroborate the results obtained from this initial study. However, these results confirm that RFLP analyses will be useful for rose cultivar identification and may, therefore, provide a powerful means of protecting patent rights of new cultivars. In addition, RFLP profiles can also ensure that purchased cultivars are what they are portrayed to be; that is, RFLP profiles can be used to certify a cultivar's identity.

\section{Literature Cited}

Apuya, R., B. Frazier, P. Keim, E.J. Roth, and K. Lark. 1988. Restriction fragment length polymorphisms as genetic markers in soybean, Glycine max (L.) Merril. Theoretical Applied Genet. 75:889-901.

Bernatzky, R. and S.D. Tanksley. 1986. Genetics of actin-related sequences in tomato. Theoretical Applied Genet: 72:314-321.

Bunce. N.. B. Forde. M. Kreis. and P. Shewry. 1986. DNA restriction fragment length polymorphism at hordein loci: application to identifying and fingerprinting barley cultivars. Seed Sci. and Technol. 14:419-429.

Feinberg, A.P. and B. Vogelstein. 1983. A technique for radiolabeling DNA restriction endonuclease fragments to high specific activity. Anal. Biochem. 132:6-13.

Gebhardt, C., C. Blomendahl, U. Schachtschabel, T. Debener, F. Salamini, and E. Ritter. 1989. Identification of $2 n$ breeding lines and $4 n$ varieties of -potato (Solanum tuberosum, ssp. tuberosum) with RFLP-fingerprints. Theoretical Applied Genet. 78:16-22.

Helentjaris. T.. M. Slocum. S. Wright. A. Schaefer, and J. Nienhuis. 1986. Construction of genetic linkage maps in maize and tomato using restriction fragment length polymorphisms. Theoretical Applied Genet. 72:761-769.

Kuhns, L.J. and T.A. Fretz. 1978. Distinguishing rose cultivars by polyacrylamide gel electrophoresis. II. Isoenzyme variation among cultivars. J. Amer. Soc. Hort. Sci. 103:509-516.

Maniatis. T.. E.F. Fritsch. and J. Sambrook. 1982. Molecular cloning: A laboratory manual. Cold Spring Harbor Laboratory, Cold Spring Harbor, N.Y.

Messing, J. 1983. New M13 vectors for cloning. Methods Enzymol. 101:20-78.

Murphy, R.W., J.W. Sites, Jr., D.G. Buth, and C.H. Haufler. 1990 , p. $45-126$. In: D.M. Hillis and C. Moritz (eds.). Molecular systematics. Sinauer Assocs., Sunderland, Mass.

Southern, E.M. 1975. Detection of specific sequences among DNA fragments separated by gel electrophoresis. J. Mol. Biol. 98:503-517.

Tankaley, S.D., L. Miller, A. Patterson, and R. Bernatzky. 1988, p. 157-173. In: J.F. Gustafson and R. Appels (eds.). Chromosome structure and function. Plenum, N.Y. 